\title{
Mountain Fork Archaeology: A Preliminary Report on the Ramos Creek Site (34MC1030)
}

Elsbeth L. Dowd

Lyme Art Association

Follow this and additional works at: https://scholarworks.sfasu.edu/ita

Part of the American Material Culture Commons, Archaeological Anthropology Commons, Environmental Studies Commons, Other American Studies Commons, Other Arts and Humanities Commons, Other History of Art, Architecture, and Archaeology Commons, and the United States History Commons

Tell us how this article helped you.

This Article is brought to you for free and open access by the Center for Regional Heritage Research at SFA ScholarWorks. It has been accepted for inclusion in Index of Texas Archaeology: Open Access Gray Literature from the Lone Star State by an authorized editor of SFA ScholarWorks. For more information, please contact cdsscholarworks@sfasu.edu. 


\section{Mountain Fork Archaeology: A Preliminary Report on the Ramos Creek Site}

(34MC1030)

\section{Creative Commons License}

\section{(c) (1) (8)}

This work is licensed under a Creative Commons Attribution-NonCommercial 4.0 International License 


\section{MOUNTAIN FORK ARCHAEOLOGY: A PRELIMINARY REPORT ON THE RAMOS CREEK SITE (34MC1030)}

\section{Elsbeth Linn Dowd}

\section{Introduction}

In May-June of 2010, the University of Oklahoma and the Oklahoma Archeological Survey co-sponsored a field school at the Ramos Creek site (34MC1030) in southeastern Oklahoma. Ramos Creek is located in the Ouachita Mountains along the Mountain Fork, a tributary of the Little River. Recently identified by the U.S. Forest Service (USFS), this site is the northernmost known site with a Caddo component along this stream (Figure 1). The best-known Caddo sites identified for this drainage were tested during the Oklahoma River Basin Survey project of the 1960s and today are covered by the man-made Broken Bow Lake. Archaeological investigations along the Mountain Fork have been conducted by Wyckoff $(1961,1965,1966,1967 a, 1967 b$, 1967c, 1968), Klinger and Cande (1987), Perttula et al. (1998), and Perttula and Nelson (2004). This past summer's work at Ramos Creek is part of a broader research program addressing several questions:

$>$ What was the relationship of Ramos Creek to sites further downstream, including the multimound Woods Mound Group?

$>$ How were the Caddo sites in this drainage organized politically and what social dynamics shaped their history? Is there a better way of understanding the socio-political organization of these communities than applying models used in other parts of the Caddo area and the wider Southeast?

$>$ How were these communities related to those living in other parts of the Caddo archaeological area, including the rest of the Ouachita Mountains, the Little River Valley, the Red River Valley, and the Arkansas Valley?

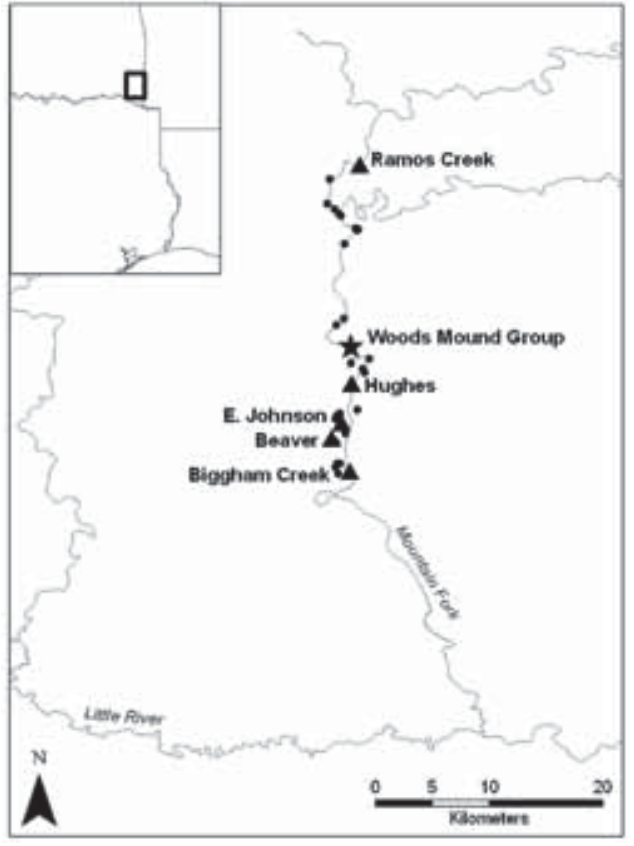

Figure 1. Ramos Creek site in relation to other Caddo sites along the Mountain Fork.

These questions form the basis of my dissertation research, which will examine the socio-political dynamics of communities living along the Mountain Fork during the late prehistoric period. This paper serves as a preliminary report on the field school at Ramos Creek. 


\section{Setting}

The Ramos Creek site is located within the Ouachita National Forest in southeastern Oklahoma. It is within the Ouachita Mountains physiographic region, at the very eastern end of the Boktuklo Mountains where that range hooks south. The site is on a terrace along the Mountain Fork, which flows south out of the mountains into the Little River. Although the river valley is narrow downstream, it is wider from this point northward. The site is on a heavily forested pine plantation.

\section{Excavations}

During the initial site survey the USFS recovered a variety of artifacts from shovel tests, including dart points, pottery, and charred maize cobs. The stratigraphy and artifacts indicated that the site contained multiple components, including a late prehistoric component. In the summer of 2009, a 1x2 m unit was excavated where the maize cobs were recovered. At $20-25 \mathrm{~cm}$ below the surface a number of artifacts were observed, including charred wood, more charred maize, daub, and fire cracked rock. These materials were present to a depth of 35 $\mathrm{cm}$ below the surface. No features were detected, though. Based on the hypothesis that these deposits were associated with a structure, work was stopped until a broader area could be excavated.

Goals for the 2010 field school included constructing a topographic map of the site, conducting intensive shovel tests across the terrace, and opening test units near known artifact concentrations (Figure 2). 145 shovel tests were put in across the eastern and western portions of the landform; 104 were positive. Locations for excavation were determined based on artifact concentrations recovered during the USFS survey, the indications of a structure at the test unit, and the close-interval shovel testing conducted by the field school. Two sets of units (Blocks 1 and 2) were opened on the eastern side of the site near the potential structure and a third set of units (Block 3) was opened on the western side of the site. Each excavation unit was identified by the location of its southwest corner along an arbitrary grid. Blocks 1 and 2 contained features directly related to the Caddo component. Block 3 contained no Caddo features, although pottery was found in the upper levels. The lower levels of Block 3, however, revealed a burned rock cluster associated with three Dalton point fragments. This feature was an exciting discovery that will complement other investigations of Early Archaic sites in the Ouachita National Forest (Coleman et al. 2009:36-39; Coleman 2010).

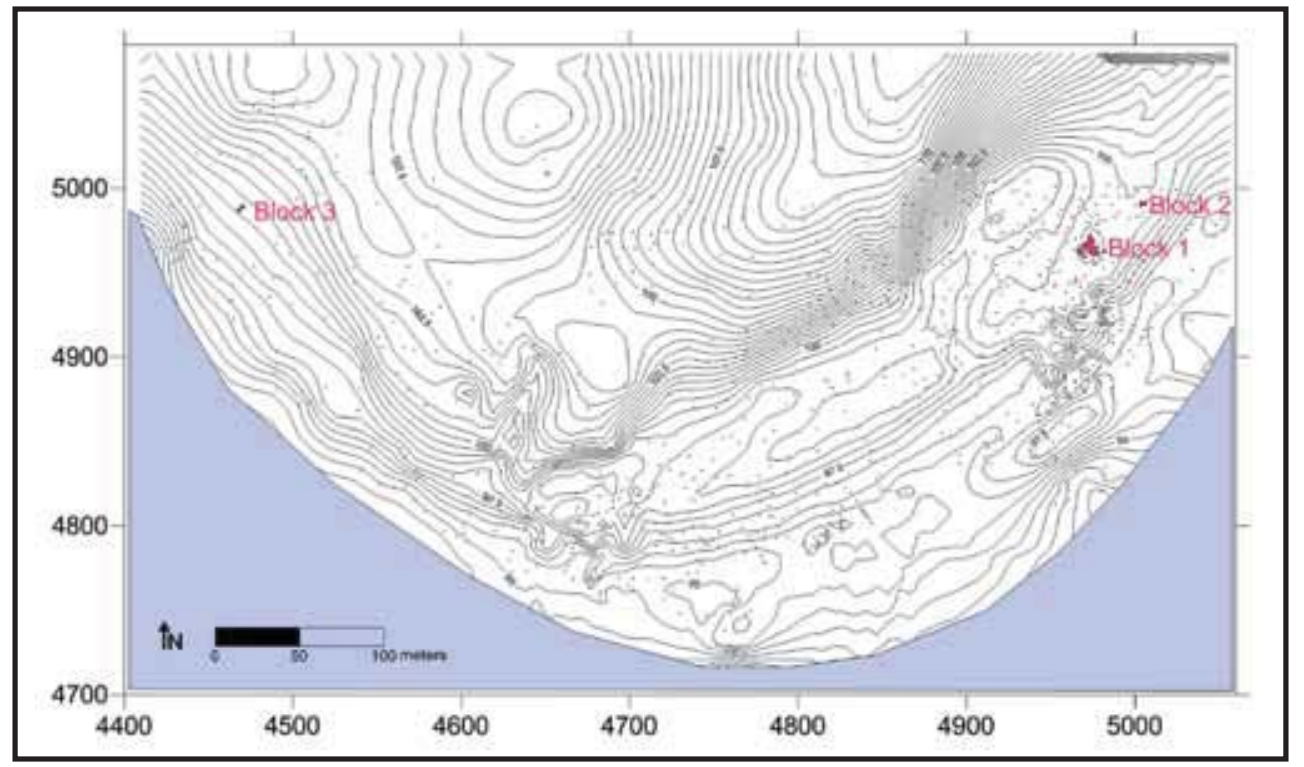

Figure 2. Map of Ramos Creek site, showing the distribution of shovel tests and excavations conducted by the field school. 
Preservation of some organic materials at Ramos Creek was remarkably good for southeastern Oklahoma. Although no faunal remains were recovered, charred maize cobs were found in Block 1. Soil samples from the Caddo component are currently undergoing flotation to examine the subsistence practices of this community.

\section{Block 1}

Block 1 was located on the eastern end of the site, at the location where the charred maize cobs were found and the presence of a structure was hypothesized. The field school excavated 59 square meters, exposing most of a rectilinear structure (Figure 3). Because the site is heavily forested not all of the structure could be uncovered, but fortunately most of the large trees missed the floor area. Level depths were standardized across the excavation area in relation to the elevations measured by the total station, using the elevation of the southwest corner of each unit. Units were excavated in 10-cm levels to a depth of 99.85 (in the center of the structure this was $20 \mathrm{~cm}$ below datum) and thereafter in 5-cm levels to subsoil ( $45-50 \mathrm{~cm}$ below datum). Excavation in units outside of the structure did not continue all the way to subsoil because of time constraints.

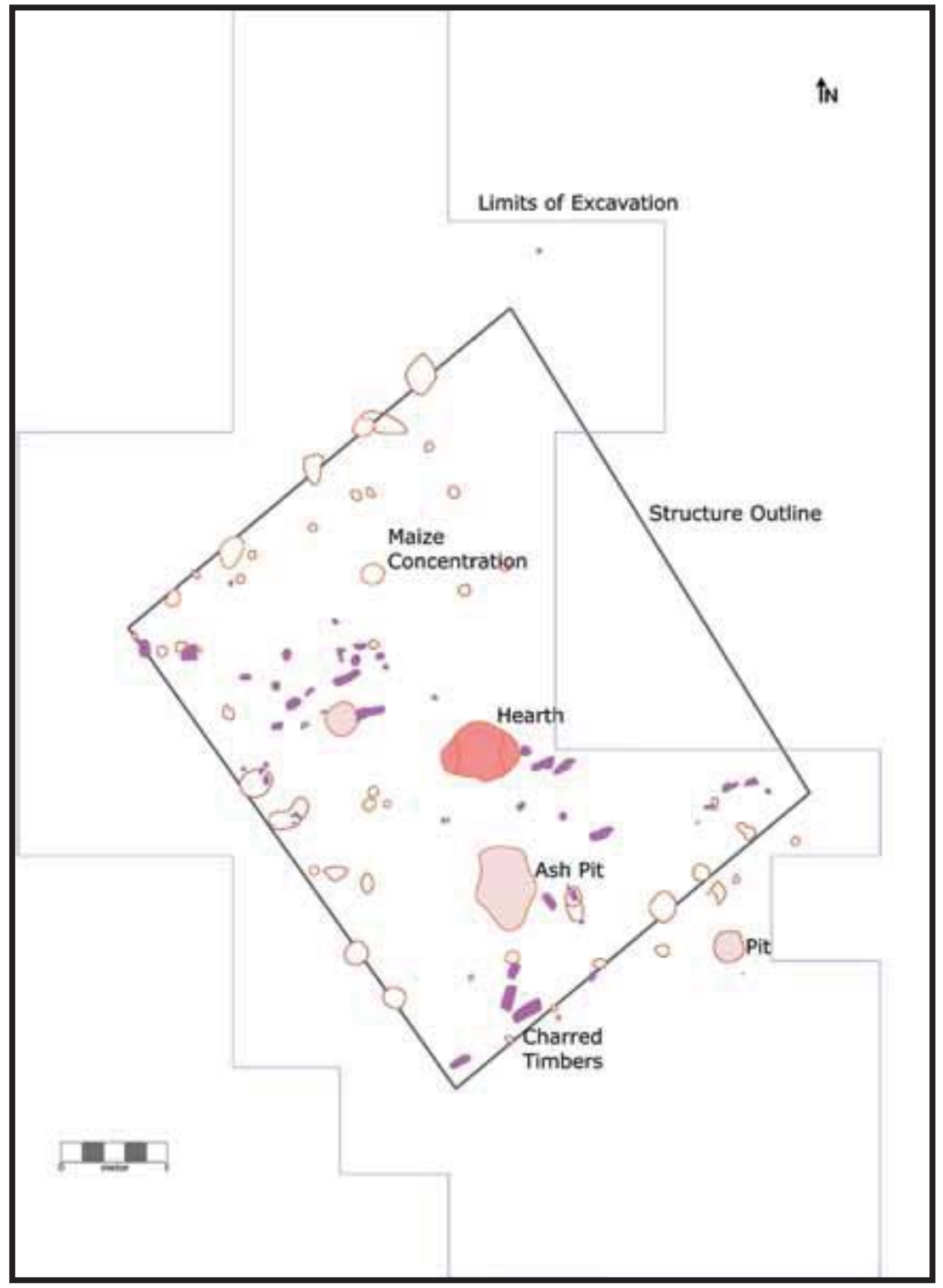

Figure 3. Outline of structure, features, and charred timbers in Block 1. 
Sediments within the structure consisted of a dark brown to dark yellowish brown sandy silt A-horizon overlying a mottled dark brown to very dark grayish brown cultural horizon. A dark yellowish brown sandy silt C-horizon (subsoil) was beneath the cultural horizon within the structure and beneath the A-horizon outside the structure. No B-horizon development was apparent in Block 1. These sediments are part of the CedaRubble alluvial complex (Soil Survey Staff).

The structure became visible approximately $25-35 \mathrm{~cm}$ below the surface, when a dark grayish brown to black outline and charred timbers appeared. The charred timbers were all located within the perimeter of the structure, suggesting that the structure was intentionally burned, pushed in on itself, and smothered. Features, including a central hearth, ash-filled pit, and post holes, became apparent at about 35-45 cm below the surface. The presence of these features and a number of larger artifacts lying horizontally at this level imply that the living surface of the structure was probably about $40 \mathrm{~cm}$ below the present ground surface. The structure was rectangular in plan, possibly with rounded corners, and measured about 5.5 by 4.5 meters. The long axis was oriented NW-SE (132 degrees east of true north). No entrance was detected, but a lower density of artifacts along the southwest side may imply that the entrance was located along this wall. This cannot be confirmed because trees prevented the excavation of the opposite wall.

Features associated with the structure include a central hearth, an ash-filled pit to the south of the hearth (F6), a cluster of charred maize cobs northwest of the hearth, a pit outside the southeast edge of the structure (F13), and post holes. A number of large flat rocks that may have functioned as cooking platforms or grinding surfaces were located near the hearth (Figure 4). One deep center post hole (F16) was located one meter west of the hearth. It measured $25 \mathrm{~cm}$ in diameter at the floor level and $8 \mathrm{~cm}$ in diameter at its base. This post hole extended $120 \mathrm{~cm}$ below the surface and $80 \mathrm{~cm}$ below the floor of the structure.

It was difficult to confirm whether certain soil stains were actually post holes, because of the large quantity of roots and leaching in this well-drained sandy pine forest soil. The high level of charcoal fragments and pieces of charred timber embedded within some of these stains and the relationship of the stains to the perimeter of the structure supported the interpretation that many were indeed post holes. The post holes around the perimeter of the structure tended to measure either $20-28$ or $15 \mathrm{~cm}$ in diameter. Along the northwest wall, where the post holes were best-defined, they were regularly spaced about $70 \mathrm{~cm}$ apart. Other definite and probable post holes around the perimeter confirm this pattern. A series of smaller post holes inside the northwest wall measuring about $10 \mathrm{~cm}$ in diameter may indicate a rebuilding episode, the need for additional support, or the presence of a bench or other platform.

Concentrations of daub were present in small quantities throughout the structure, especially near the hearth and in the northwest section. The largest piece was no more than $5 \mathrm{~cm}$ long and most pieces were nickel-sized or smaller. None contained impressions of building materials.

Pottery sherds ( $\mathrm{n}=471$, including 93 diagnostic), lithic debitage $(\mathrm{n}=5012)$, and chipped- $(\mathrm{n}=36)$, ground- $(n=7)$, and pecked-stone tools $(n=4)$ were all found in Block 1 (Table 1). Artifact analysis is ongoing, but diagnostic sherds included red-slipped sherds from a carinated bowl, compound bowl, and bottle along with incised sherds with applique strips and ridge-pinched neck banding from jars (Figure 5). Point types included Reed, Fresno, and Scallorn. The points and debitage consist of local raw materials including Big Fork chert, John's Valley chert variants, novaculite, siltstone, and quartzite. The lithic tools were most densely concentrated near the hearth and in the southeast part of the structure. Pottery and lithic debitage were more evenly distributed across the structure, although a larger number of identifiable clusters of pottery sherds were located in the southeast part of the structure. This may indicate that this area was used for storage or food preparation. The presence of large rock slabs to the southeast of the hearth further supports this interpretation. 


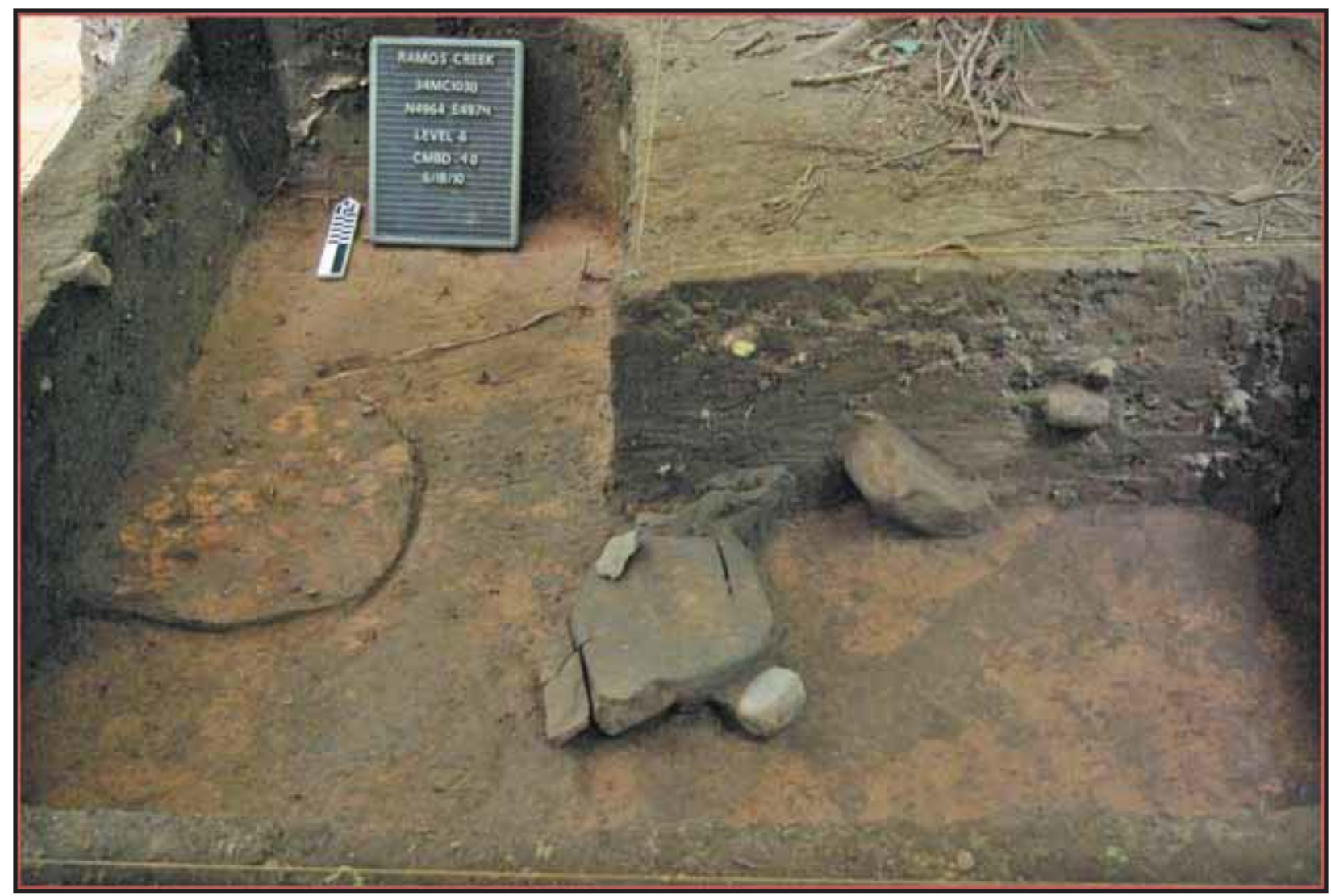

Figure 4. Central hearth from Block 1 structure and nearby rocks and ground stone, $40 \mathrm{~cm}$ below datum.

Quartz ( $\mathrm{n}=196$, weight=394.4 g) and fire-cracked rock ( $\mathrm{n}=3304$, weight=31,485 g) were also present in Block 1. It is likely that most of the quartz is natural, because quartz crystals were widely distributed across the site and large quartz veins occur nearby (Miser 1943). The quartz will be further examined for evidence of modification. The quantity of fire-cracked rock in the Block 1 structure was large, but not unexpected for a burned structure in a shale-rich alluvial soil. Interestingly, the distribution of fire-cracked rock within the structure mirrors the distribution of debitage. In both cases a much lower concentration occurred within the middle of the southwest wall, suggesting the potential presence of an entrance on this side (as discussed before).

Table 1. Artifacts from 2010 Excavations at Ramos Creek.

\begin{tabular}{|c|c|c|c|c|c|c|c|c|c|c|}
\hline \multirow[t]{2}{*}{ Provenience } & \multicolumn{2}{|c|}{ Pottery } & \multirow{2}{*}{$\begin{array}{c}\text { Lithic } \\
\text { Debitage } \\
\text { (n) }\end{array}$} & \multirow{2}{*}{$\begin{array}{c}\text { Chipped } \\
\text { Stone } \\
\text { Tools (n) }\end{array}$} & \multirow{2}{*}{$\begin{array}{c}\text { Ground } \\
\text { Stone } \\
\text { Tools } \\
\text { (n) }\end{array}$} & \multirow{2}{*}{$\begin{array}{l}\text { Pecked } \\
\text { Stone } \\
\text { Tools } \\
\text { (n) } \\
\end{array}$} & \multicolumn{2}{|c|}{ Quartz } & \multicolumn{2}{|c|}{ FCR } \\
\hline & $\begin{array}{l}\text { All } \\
\text { Sherds } \\
\text { (n) }\end{array}$ & $\begin{array}{l}\text { Diagnostic } \\
\text { Sherds (n) }\end{array}$ & & & & & n & $\begin{array}{c}\text { weight } \\
\text { (g) }\end{array}$ & n & $\begin{array}{c}\text { weight } \\
\text { (g) }\end{array}$ \\
\hline $\begin{array}{c}\text { Block } 1 \\
\text { (structure) }\end{array}$ & 471 & 93 & 5012 & 36 & 7 & 4 & 196 & 394.4 & 3304 & 31,485 \\
\hline Block 2 & 218 & 22 & 651 & 7 & 0 & 0 & 24 & 40.4 & 180 & 3,753 \\
\hline Block 3 & 115 & 16 & 1036 & 15 & 0 & 0 & 10 & 15.1 & 272 & 3,984 \\
\hline Shovel Tests & 23 & 4 & 373 & 4 & 0 & 1 & 4 & 3.6 & 116 & 3,904 \\
\hline Total & 827 & 135 & 7217 & 64 & 7 & 5 & 234 & 453.5 & 3,872 & 43,126 \\
\hline
\end{tabular}



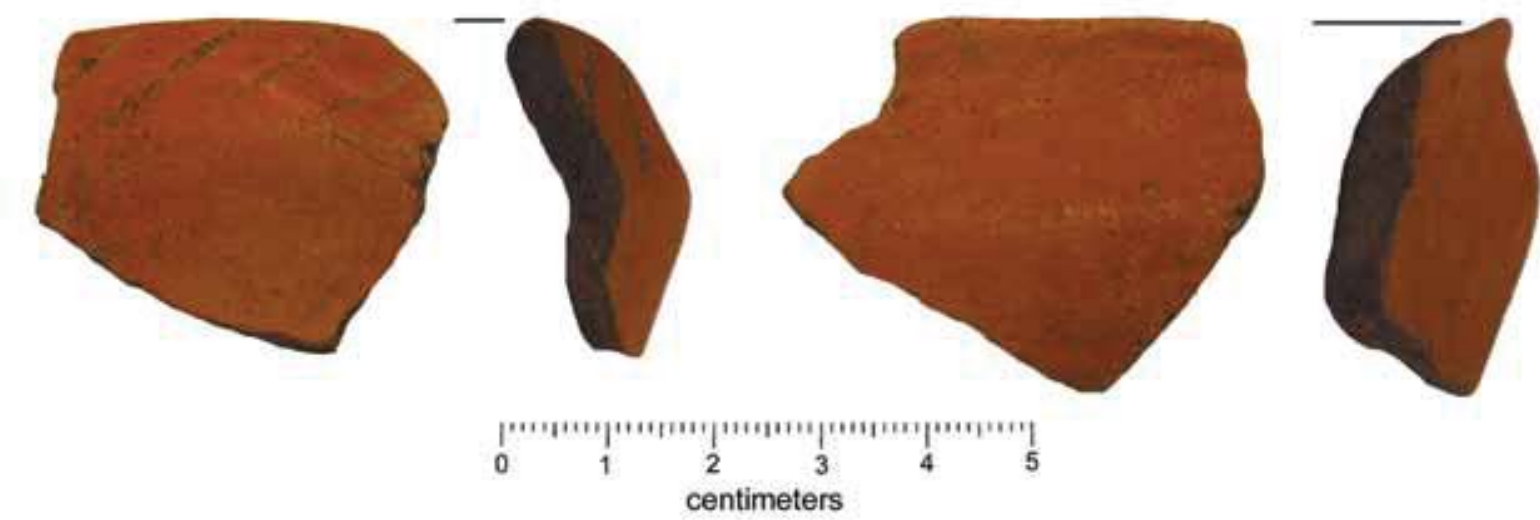

Figure 5. Two red-slipped pottery sherds from structure in Block 1.

\section{Radiocarbon Dating}

Twelve radiocarbon dates (3 AMS and 9 radiometric; Table 2) were obtained from charcoal samples from the Block 1 structure. The samples included charcoal from post holes and from charred timbers. At 2 sigma, the calibrated dates range from A.D. 1230 to 1630 (Figure 6). The pooled dates yielded a calibrated age of A.D. 1319-1350 or 1391-1412 (Buck et al. 1999; Figure 7). These date ranges compare well to calibrated dates from Woods Mound Group (34MC104) and place the Block 1 structure within the later part of the middle Caddo period (ca. A.D. 1200-1400).

Table 2. Radiocarbon dates from the Ramos Creek site (34MC1030).

\begin{tabular}{|c|c|c|c|c|c|c|c|c|}
\hline Lab \# & $\begin{array}{c}\text { AMS or } \\
\text { Radiometric }\end{array}$ & $\begin{array}{c}\text { Measured } \\
\text { Radiocarbon } \\
\text { Age (BP) }\end{array}$ & $\begin{array}{c}13 \mathrm{C} / 12 \mathrm{C} \\
\text { Ratio }\end{array}$ & $\begin{array}{c}\text { Conventional } \\
\text { Radiocarbon } \\
\text { Age (BP) }\end{array}$ & $\begin{array}{l}\text { 2 Sigma } \\
\text { Calibration } \\
\text { (AD) }\end{array}$ & $\begin{array}{l}\text { Intercept of } \\
\text { radiocarbon } \\
\text { age with cal } \\
\text { curve (AD) }\end{array}$ & Catalog No. & Provenience \\
\hline $\begin{array}{c}\text { Beta- } \\
284398\end{array}$ & Radiometric & $410 \pm 40$ & $-25.7 \mathrm{o} / \mathrm{oo}$ & $400 \pm 40$ & $\begin{array}{c}1430-1530 \\
\text { and } \\
1560-1630\end{array}$ & 1460 & OUA10_20_385 & $\begin{array}{l}\text { N4964 E4974, } \\
\text { 26-30 cmbd, } \\
\text { charred timber }\end{array}$ \\
\hline $\begin{array}{c}\text { Beta- } \\
284390\end{array}$ & AMS & $520 \pm 40$ & $-27.9 \mathrm{o} / \mathrm{oo}$ & $470 \pm 40$ & $1410-1460$ & 1440 & OUA10_20_159 & $\begin{array}{l}\text { N4966 E4972, } \\
34 \mathrm{cmbd}, \\
\text { post hole }\end{array}$ \\
\hline $\begin{array}{c}\text { Beta- } \\
284391\end{array}$ & Radiometric & $550 \pm 50$ & $27.1 \mathrm{o} / \mathrm{oo}$ & $510 \pm 50$ & $\begin{array}{c}1320-1350 \\
\text { and } \\
1390-1450\end{array}$ & 1420 & OUA10_20_234 & $\begin{array}{l}\text { N4964 E4970, } \\
\text { charred timber }\end{array}$ \\
\hline $\begin{array}{c}\text { Beta- } \\
267780\end{array}$ & AMS & $530 \pm 40$ & $-25.8 \mathrm{o} / \mathrm{oo}$ & $520 \pm 40$ & $\begin{array}{c}1320-1350 \\
\text { and } \\
1390-1440\end{array}$ & 1420 & OUA10_20_449 & $\begin{array}{c}\text { N4966 E4972, } \\
\text { 30-35 cmbd, } \\
\text { charcoal }\end{array}$ \\
\hline $\begin{array}{c}\text { Beta- } \\
284396\end{array}$ & Radiometric & $560 \pm 40$ & $-26.3 \mathrm{o} / \mathrm{oo}$ & $540 \pm 40$ & $\begin{array}{c}1310-1360 \\
\text { and } \\
1390-1440\end{array}$ & 1410 & OUA10_20_355 & $\begin{array}{l}\text { N4964 E4972, } \\
\text { 20-24 cmbd, } \\
\text { charred timber }\end{array}$ \\
\hline $\begin{array}{c}\text { Beta- } \\
284392\end{array}$ & AMS & $590 \pm 40$ & $-26.8 \mathrm{o} / \mathrm{oo}$ & $560 \pm 40$ & $\begin{array}{c}1300-1370 \\
\text { and } \\
1380-1430\end{array}$ & 1400 & OUA10_20_266 & $\begin{array}{l}\text { N4966 E4972, } \\
33 \mathrm{cmbd}, \\
\text { post hole }\end{array}$ \\
\hline $\begin{array}{c}\text { Beta- } \\
284397\end{array}$ & Radiometric & $640 \pm 50$ & $-27.1 \mathrm{o} / \mathrm{oo}$ & $610 \pm 50$ & $1280-1420$ & $\begin{array}{c}1320 \text { and } \\
1350 \text { and } \\
1390\end{array}$ & OUA10_20_372 & $\begin{array}{l}\text { N4964 E4972, } \\
20-25 \text { cmbd, } \\
\text { charred timber }\end{array}$ \\
\hline $\begin{array}{c}\text { Beta- } \\
284399\end{array}$ & Radiometric & $650 \pm 50$ & $-26.1 \mathrm{o} / \mathrm{oo}$ & $630 \pm 50$ & $1280-1420$ & $\begin{array}{l}1310 \text { and } \\
1360 \text { and } \\
1380\end{array}$ & OUA10_20_417 & $\begin{array}{c}\text { N4962 E4974, } \\
33 \mathrm{cmbd}, \\
\text { post hole }\end{array}$ \\
\hline $\begin{array}{c}\text { Beta- } \\
284393\end{array}$ & Radiometric & $650 \pm 50$ & $-25.6 \mathrm{o} / \mathrm{oo}$ & $640 \pm 50$ & $1270-1410$ & $\begin{array}{c}1300 \text { and } \\
1370 \text { and } \\
1380\end{array}$ & OUA10_20_268 & $\begin{array}{l}\text { N4962 E4974, } \\
20-25 \mathrm{cmbd,} \\
\text { charred timber }\end{array}$ \\
\hline $\begin{array}{c}\text { Beta- } \\
284394\end{array}$ & Radiometric & $690 \pm 40$ & $-25.6 \mathrm{o} / \mathrm{oo}$ & $680 \pm 40$ & $\begin{array}{c}1270-1320 \\
\text { and } \\
1350-1390\end{array}$ & 1290 & OUA10_20_353 & $\begin{array}{l}\text { N4964 E4972, } \\
21-24 \text { cmbd, } \\
\text { charred timber }\end{array}$ \\
\hline $\begin{array}{c}\text { Beta- } \\
284400\end{array}$ & Radiometric & $710 \pm 50$ & $-26.2 \mathrm{o} / \mathrm{oo}$ & $690 \pm 50$ & $\begin{array}{c}1260-1330 \\
\text { and } \\
1340-1400\end{array}$ & 1290 & OUA10_20_422 & $\begin{array}{c}50 \mathrm{cmbd}, \\
\text { post hole }\end{array}$ \\
\hline $\begin{array}{c}\text { Beta- } \\
284395\end{array}$ & Radiometric & $730 \pm 50$ & $-25.9 \mathrm{o} / \mathrm{oo}$ & $710 \pm 50$ & $\begin{array}{c}1230-1320 \\
\text { and } \\
1350-1390 \\
\end{array}$ & 1280 & OUA10_20_354 & $\begin{array}{l}\text { N4964 E4972, } \\
\text { 20-24 cmbd, } \\
\text { charred timber }\end{array}$ \\
\hline
\end{tabular}




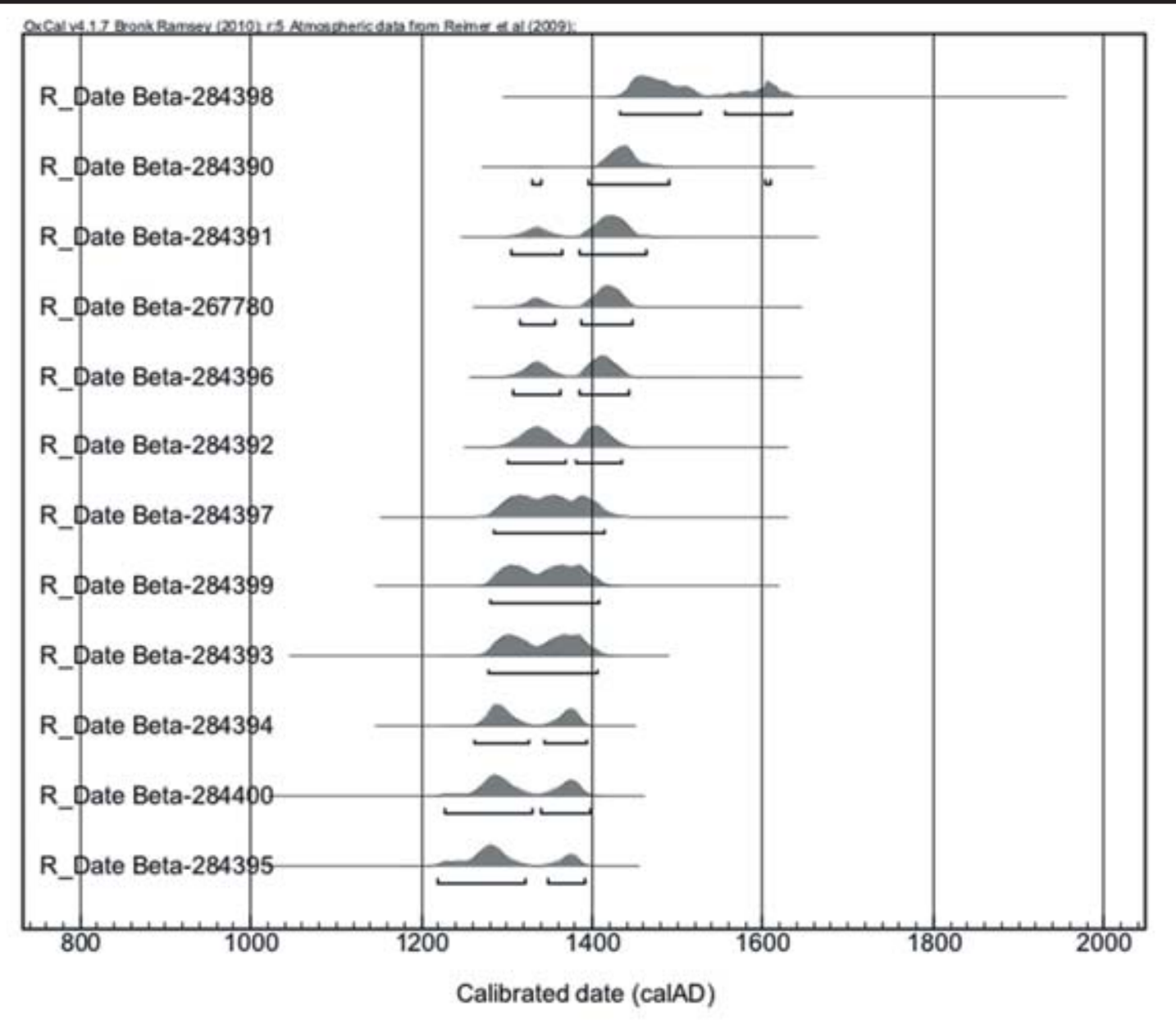

Figure 6. Ramos Creek dates from structure at Ramos Creek, calibrated using OxCal 4.1 with IntCal 09 curve.

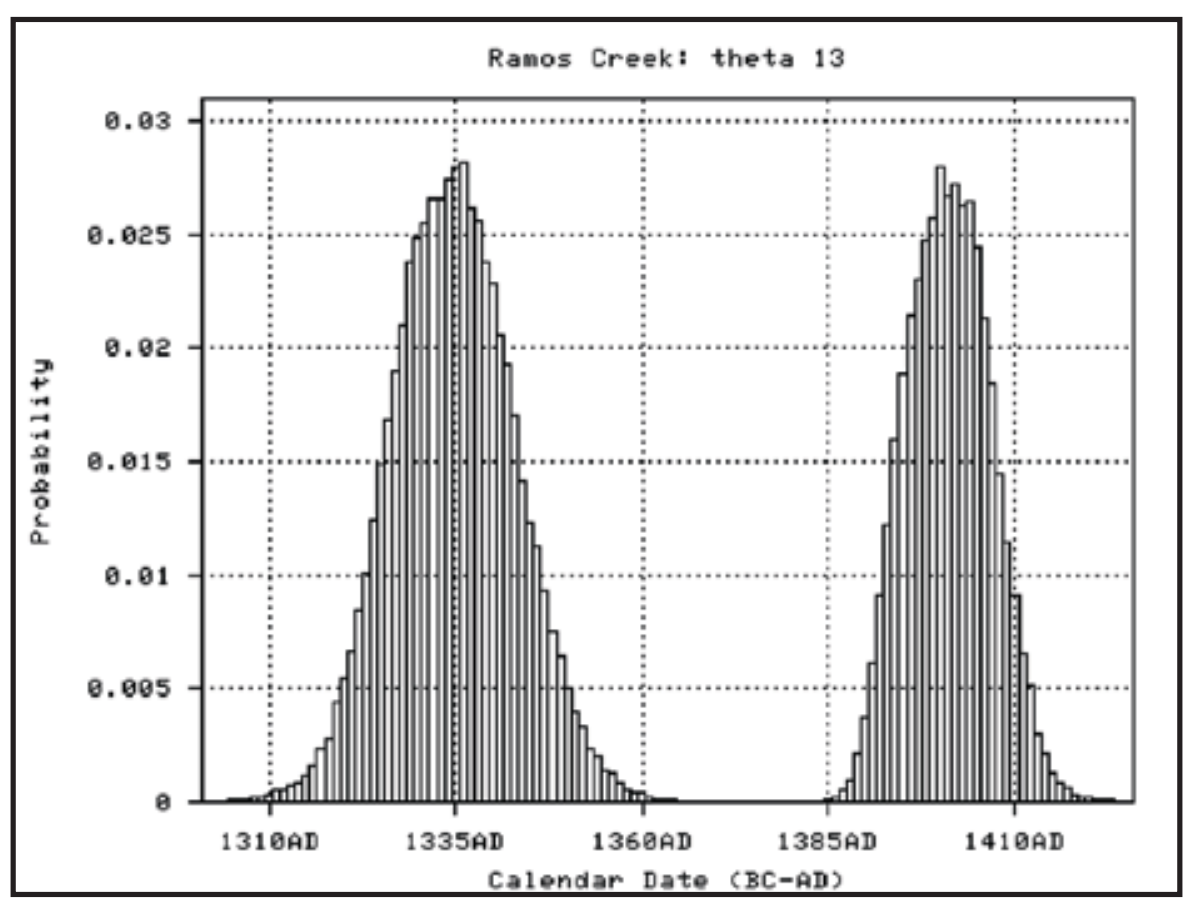

Figure 7. Pooled and calibrated radiocarbon dates from Caddo structure at Ramos Creek, using http://bcal.sheffield.ac.uk (Buck et al. 1999) with IntCal09. 


\section{Block 2}

On the second day of the field school, a shovel test exposed part of an Archaic point. This shovel test was located about 35 meters northeast of Block 1, on the same terrace landform. Two contiguous $2 \times 2 \mathrm{~m}$ units were opened next to the shovel test to examine the stratigraphy of the landform and to attempt to identify the Archaic component. We planned to excavate both units in 10-cm levels; however, a feature (F5) containing Caddo pottery was encountered $32 \mathrm{~cm}$ below the datum in the western unit.

Excavation of the western unit continued as planned. Nine 10-cm levels were excavated. The first four levels contained the vast majority of the artifacts, which included lithic debris and pottery sherds (Table 3). This artifact concentration co-occurred with a brown to dark brown silty sand A-horizon (Figure 8). Artifact density dropped off dramatically after $40 \mathrm{cmbd}$ and no artifacts were found in Level 9. Between 40-50 cmbd a diffuse wavy boundary marked the transition to a yellowish-tan sandy silt C-horizon. At 60-70 cmbd a clear wavy boundary separated the first C-horizon from another C-horizon (2C), a dark yellowish brown to red sandy clay that grew increasingly hard. At $90 \mathrm{cmbd}$, a hand auger was used to take two cores, one in the north of the unit to $33 \mathrm{~cm}$ below the unit floor $(123 \mathrm{cmbd})$ and one in the south of the unit to $35 \mathrm{~cm}$ below the unit floor (125 cmbd). No change in the sediment occurred nor did any artifacts appear, so excavation of this unit ceased.

Table 3. Block 2: Count of Pottery Sherds and Lithic Debitage by 10-cm level in Unit N4990 E5005.

\begin{tabular}{|c|c|c|}
\hline Level & $\begin{array}{c}\text { N4990 E5005 } \\
\text { Pottery Sherds (n) }\end{array}$ & $\begin{array}{c}\text { N4990 E5005 } \\
\text { Lithic Debitage (n) }\end{array}$ \\
\hline Level 1 & 1 & 25 \\
\hline Level 2 & 2 & 54 \\
\hline Level 3 & 4 & 73 \\
\hline Level 4 & 0 & 42 \\
\hline Level 5 & 0 & 0 \\
\hline Level 6 & 0 & 4 \\
\hline Level 7 & 2 & 4 \\
\hline Level 8 & 0 & 1 \\
\hline Level 9 & 0 & 0 \\
\hline
\end{tabular}

A $1 \mathrm{x} 1$ meter unit was opened just south of the eastern unit of Block 2 to expose Feature 5 , a pit feature containing a concentration of pottery sherds. The majority of pottery from Block 2 came from this feature, including 22 diagnostic sherds. These sherds included two rim sherds from a ridge-pinched neck-banded jar with appliqué pseudo-handles (Figure 9). One handle came off when the sherd was washed, illustrating that the pseudo-handle was originally applied after the entire neck had already been ridge-pinched. 


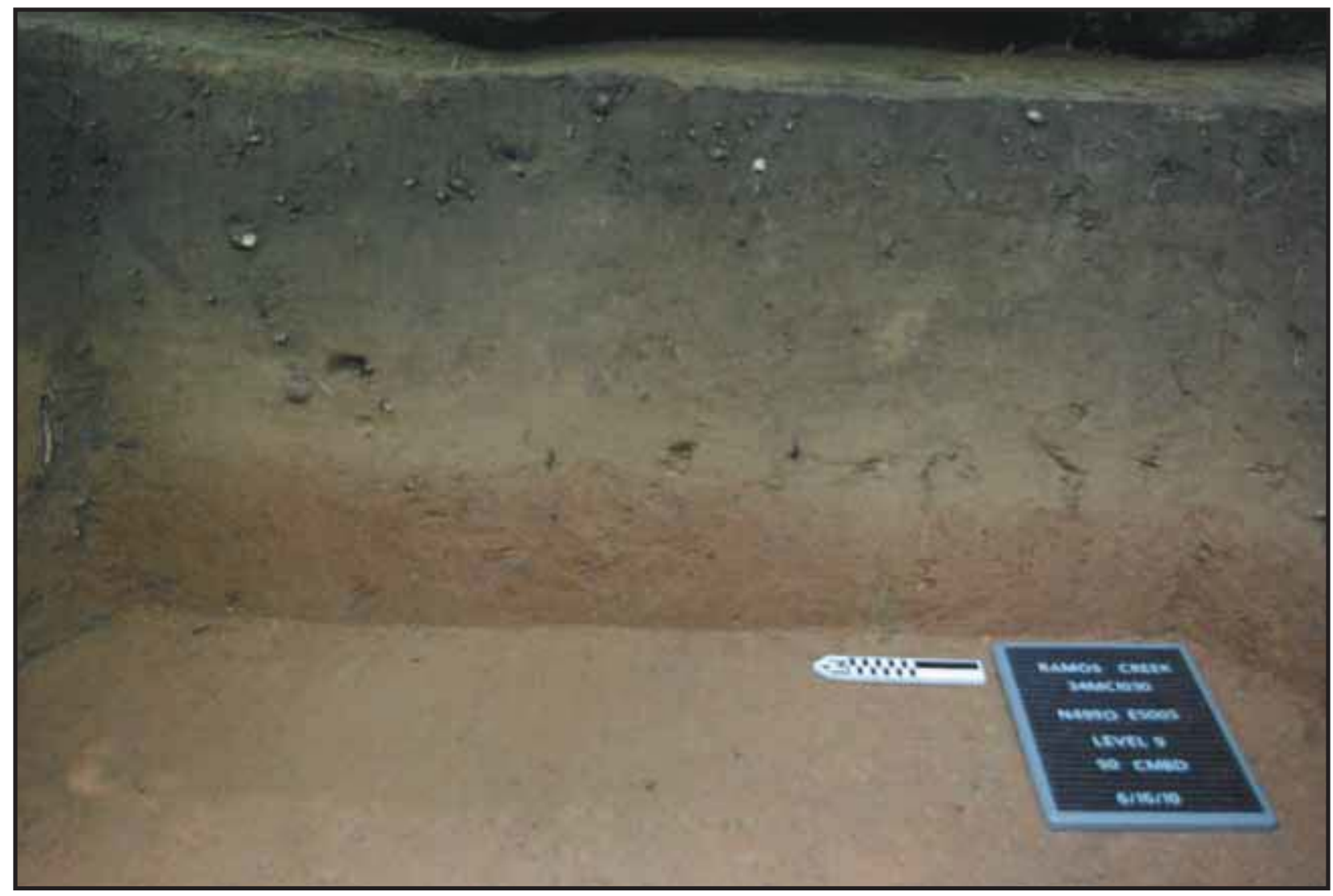

Figure 8. Block 2 profile facing east, depth $90 \mathrm{~cm}$ below datum.

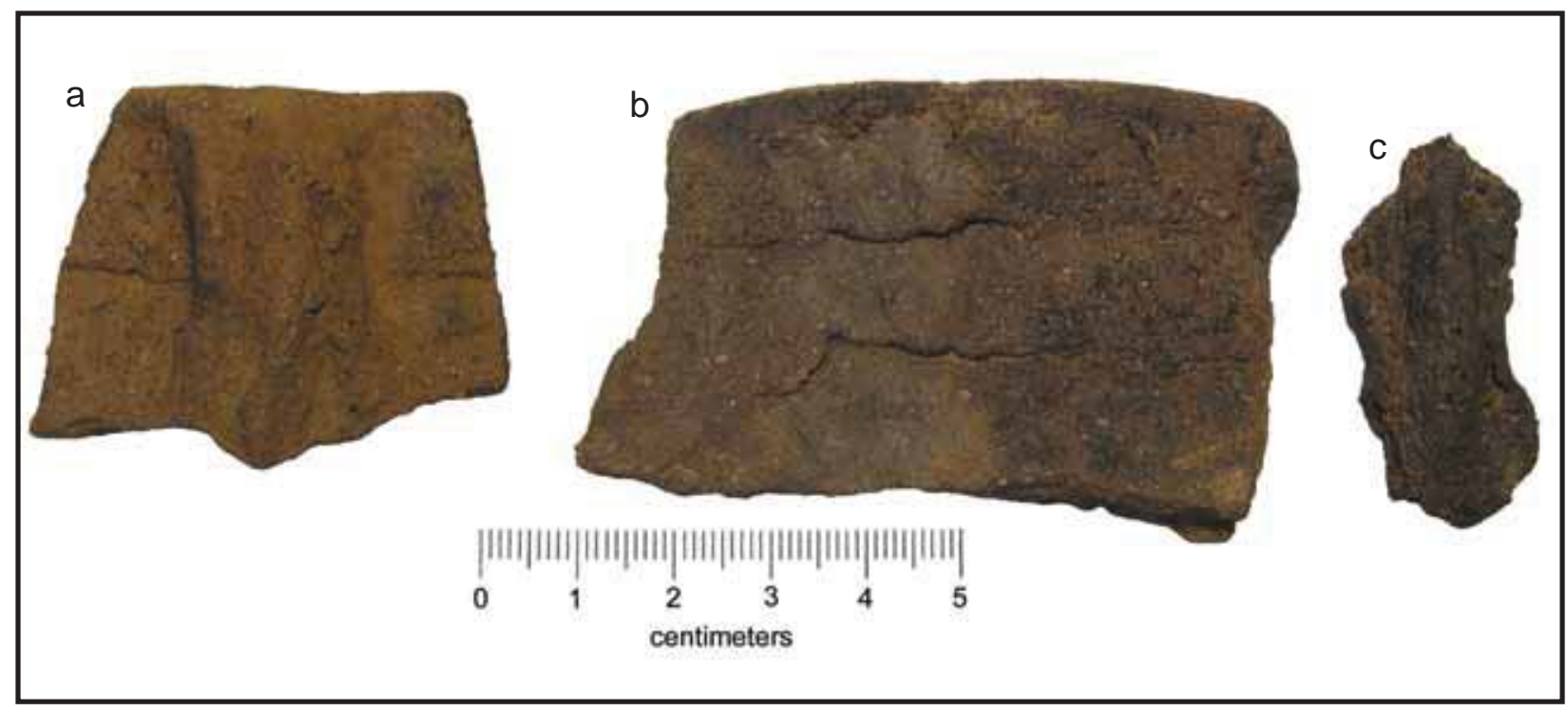

Figure 9. From Feature 5 in Block 2, a rim sherd of a ridge-pinched neck-banded jar with appliqué pseudo-handle (a). When a similar rim sherd was washed, the pseudo-handle came off, showing that the pseudo-handle was applied after the neck was ridge-pinched (b-c). 
Given the presence of the pit feature, another Caddo structure was likely in close proximity to Block 2. The features in Blocks 1 and 2 in conjunction with the distribution of pottery sherds in the shovel tests (Figure 10) indicates that the Caddo-period settlement was likely dispersed across this landform.

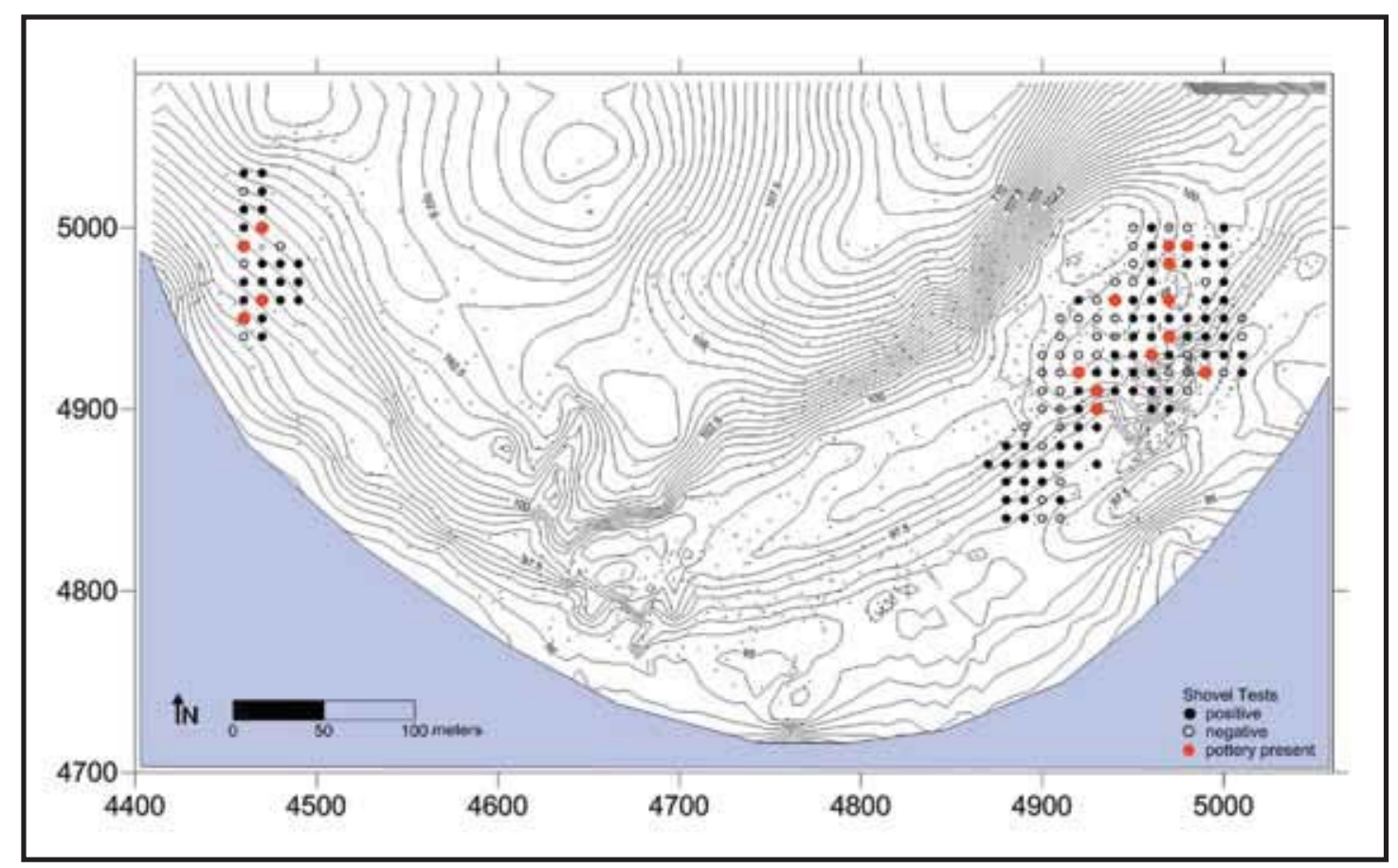

Figure 10. Map of Ramos Creek, showing the distribution of shovel tests in which pottery occurred.

\section{Block 3}

A third set of units was excavated on the west side of the site, near the location of another concentration of artifacts found during the USFS shovel tests. The sediments in this part of the site are part of the SherwoodZafra complex, which consists of weathered sediments from the bedrock sandstone and shale (Soil Survey Staff). Two $2 \times 2$ meter units were excavated in 10-cm levels. Pottery sherds were most heavily concentrated in the first three levels and disappeared entirely by Level 6 (Table 4). A gravel lens appeared at about $50 \mathrm{~cm}$ below datum, marking a boundary between the late prehistoric and Archaic components. A number of Archaic points and pieces of fire-cracked rock appeared between $50-60 \mathrm{~cm}$ below datum.

Table 4. Block 3: Counts of Pottery Sherds and Lithic Debitage by 10-cm level.

\begin{tabular}{|c|c|c|c|c|}
\hline Level & $\begin{array}{c}\text { N4986 E4467 } \\
\text { Pottery Sherds (n) }\end{array}$ & $\begin{array}{c}\text { N4988 E4469 } \\
\text { Pottery Sherds (n) }\end{array}$ & $\begin{array}{c}\text { N4986 E4467 } \\
\text { Lithic Debitage (n) }\end{array}$ & $\begin{array}{c}\text { N4988 E4469 } \\
\text { Lithic Debitage (n) }\end{array}$ \\
\hline Level 1 & 22 & 16 & 61 & 41 \\
\hline Level 2 & 18 & 25 & 98 & 89 \\
\hline Level 3 & 2 & 19 & 49 & 51 \\
\hline Level 4 & 2 & 7 & 66 & 74 \\
\hline Level 5 & 1 & 3 & 67 & 31 \\
\hline Level 6 & 0 & 0 & 59 & 40 \\
\hline Level 7 & 0 & 0 & 42 & 40 \\
\hline Level 8 & 0 & 0 & 25 & 44 \\
\hline Level 9 & 0 & 0 & 29 & 16 \\
\hline Level 10 & 0 & 0 & 9 & 11 \\
\hline Level 11 & 0 & 0 & 0 & \\
\hline
\end{tabular}


In the southwest unit a burned rock feature (F2) was encountered in level 7 and was fully uncovered by level 8 (Figure 11). This feature measured $120 \mathrm{~cm}$ east-west by $180 \mathrm{~cm}$ north-south. The feature extended beyond the unit and was pedestaled as the excavation continued to $110 \mathrm{~cm}$ below datum. Three Dalton point fragments were found near the feature $80-100 \mathrm{~cm}$ below datum (Figure 12). This feature may be revisited in the future.

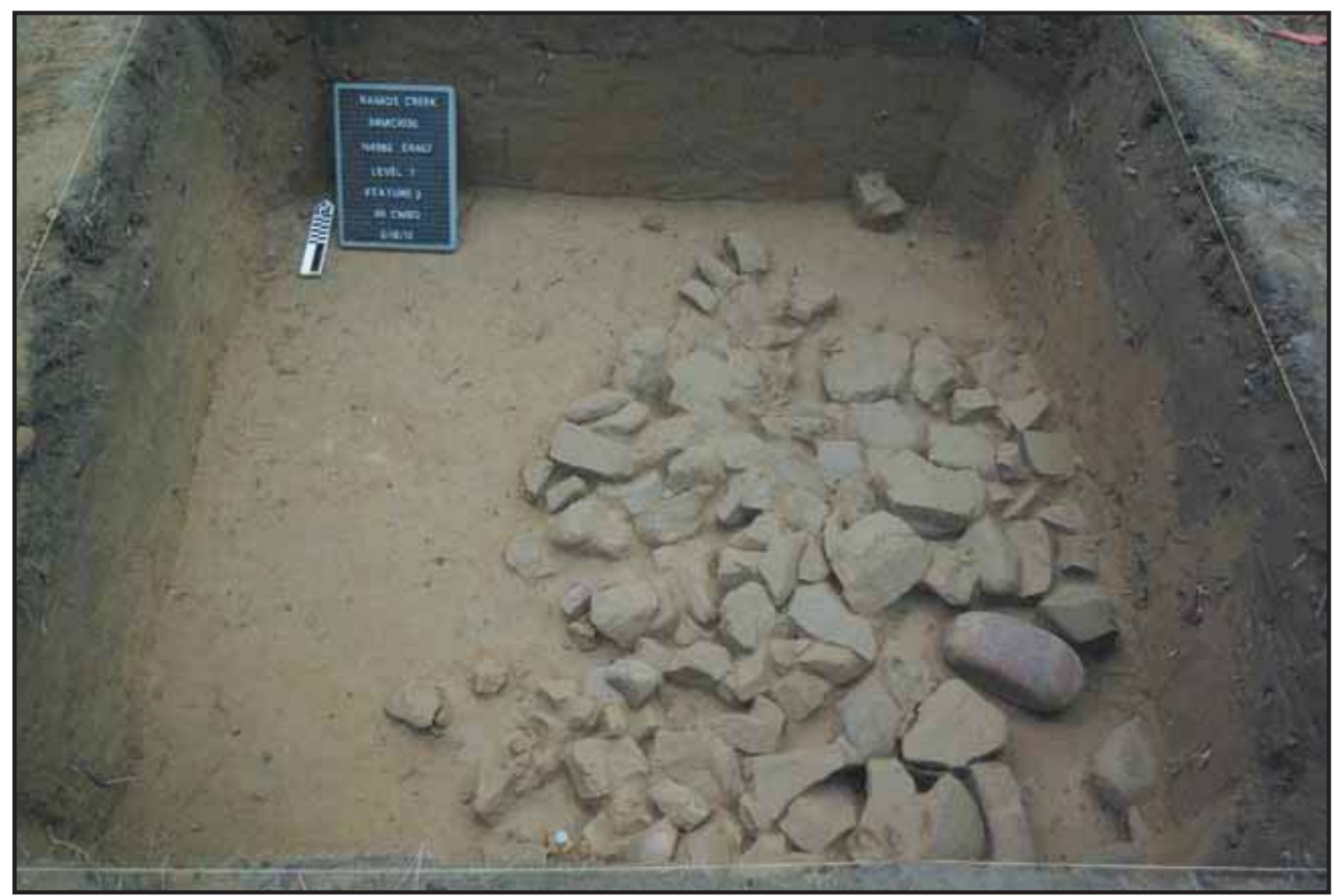

Figure 11. Burned rock feature in Block $3,80 \mathrm{~cm}$ below datum.

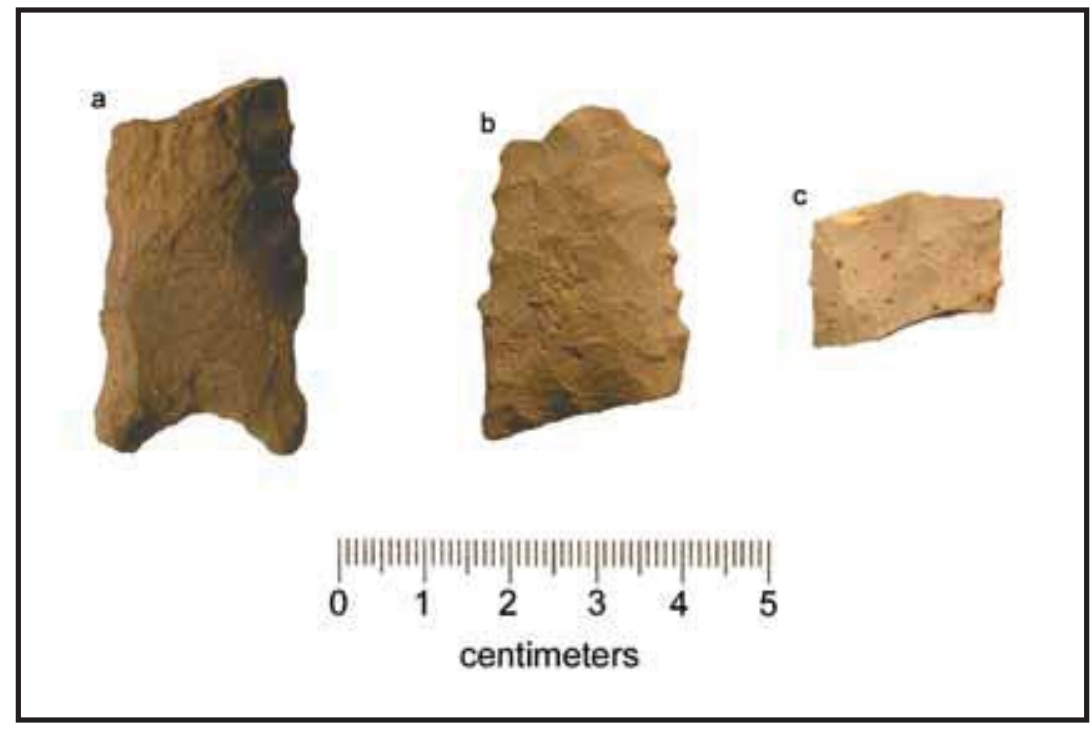

Figure 12. Dalton points from Block 3, 80-100 cm below datum. 


\section{Conclusion}

Ramos Creek has the potential to contribute significantly to our understanding of both ancestral Caddo and Archaic peoples living in the Ouachita Mountains. This paper is only a preliminary report. In the coming months the artifact and paleobotanical analyses will be completed and examined in a regional context. The results will be published in my dissertation, which will examine the sociopolitical dynamics of the ancestral Caddo living along the Mountain Fork.

\section{Acknowledgements}

All of my thanks to Patrick Livingood, Amanda Regnier, Scott Hammerstedt, Don Wyckoff, the Caddo Nation, Bert Pelletier and the U.S. Forest Service, the University of Oklahoma, the Oklahoma Archeological Survey, the Sam Noble Oklahoma Museum of Natural History, Dawn Rutecki, Tim Dowd, Michael Carlock, Truet Hinson, Jo Harrington and her family, Sarah Hunt, Allison Douglas, Chelsea Reedy, and all of our field school students and volunteers. Partial funding for this project came from the National Science Foundation and the University of Oklahoma Graduate Student Senate. This material is based upon work supported by the National Science Foundation under Grant No. BCS-1024314.

\section{References Cited}

Buck, Caitlin E., J. Andrés Christen, and Gary N. James

1999 BCal: an on-line Bayesian radiocarbon calibration tool. Internet Archaeology 7

(http://intarch.ac.uk/journal/issue7/buck/). .

Coleman, Roger E.

2010 Arkansas Dalton excavation hints at cane forest, weapon retooling. Trowel Marks 2(2):5.

Coleman, Roger E., Meeks Etchieson, Timothy K. Perttula, and Shawn Marceaux

2009 Ouachita National Forest: An Archaeological Overview. Ouachita National Forest, Hot Springs, Arkansas.

Klinger, Timothy C. and Robert C. Cande

1987 Broken Bow Lake: Cultural Resource Survey at Broken Bow Lake, McCurtain County, Oklahoma. Reports 87-7. Historic Preservation Associates, Fayetteville.

Miser, Hugh D.

1943 Quartz Veins in the Ouachita Mountains of Arkansas and Oklahoma (Their Relations to Structure, Metamorphism, and Metalliferous Deposits). Economic Geology 38(2):91-118.

Perttula, Timothy K. and Bo Nelson

2004 Archeological Investigations at Five Prehistoric Sites at Broken Bow Reservoir, McCurtain County, Oklahoma. Report of Investigations No. 49, Archeological and Environmental Consultants, LLC, Austin. 


\section{References Cited (cont.)}

Perttula, Timothy K., Dan J. Prikryl, Bo Nelson, and Robert L. Cast

1998 Archeological Survey of the Broken Bow Lake Shoreline and the Relocation and Evaluation of Nine Previously Recorded Sites, McCurtain County, Oklahoma. Report of Investigations No. 7. Archeological and Environmental Consultants, LLC, Austin.

Soil Survey Staff, Natural Resources Conservation Service, United States Department of Agriculture Web Soil Survey. Available online at http://websoilsurvey.nrcs.usda.gov/ accessed 12/6/10.

Wyckoff, Don G.

1961 Report on Archaeological Survey of Broken Bow Lake: McCurtain County, Oklahoma. MS on file, Oklahoma Archeological Survey, Norman.

1965 The Biggham Creek Site of McCurtain County, Oklahoma. Archaeological Site Report No. 3. Oklahoma River Basin Survey Project, University of Oklahoma, Norman.

1966 The Hughes, Lamas Branch, and Callaham Sites, McCurtain County, Oklahoma. Archaeological Site Report No. 4. Oklahoma River Basin Survey Project, University of Oklahoma, Norman.

1967a The Archaeological Sequence in the Broken Bow Lake Area, McCurtain County, Oklahoma. Stovall Museum of Natural History, Oklahoma River Basin Survey Project, University of Oklahoma Research Institute, Norman.

1967b The E. Johnson Site and Prehistory in Southeast Oklahoma. Archaeological Site Report No. 6. Oklahoma River Basin Survey Project, University of Oklahoma, Norman.

1967a Woods Mound Group: A Prehistoric Mound Complex in McCurtain County, Oklahoma. Bulletin of the Oklahoma Anthropological Society 15:1-76.

1968 The Beaver Site and the Archaeology of the Broken Bow Reservoir Area, McCurtain County, Oklahoma. Archaeological Site Report No. 9. Oklahoma River Basin Survey Project, University of Oklahoma, Norman. 